\title{
TAWARAN AL-QUR'AN TENTANG ISHLAH
}

\author{
Kusnadi \\ ${ }^{1}$ Institut Agama Islam Muhammadiyah Sinjai \\ E-mail:adhybugiez@gmail.com,Tlp: +628114178104
}

\begin{abstract}
Abstrak
Dari berbagai bentuk derivasi kata ishlah ditemukan beberapa arti antara lain baik atau tidak rusak, tidak binasa, saleh, damai dan bermanfaat, akan tetapi pada kajian ini menelaah tentang ishlah dalam arti "damai". Dengan tujuan yang bermuara pada terwujudnya kedamaian yang merupakan penyangga utama dalam meraih kebahagiaan. Dengan kata lain, salah satu esensi ishlah itu adalah menciptakan stabilitas yang kondusif. Dalam hal ini, Al-Qur`an merumuskan suatu jalan tentang bagaimana ishlah direaslisasikan dengan sebaik-baiknya. Proses pembahasan ishlah yang digunakan dalam kajian ini adalah kajian tematik dengan mengumpulkan berbagai ayat yang terkait dengan masalah ishlah, kemudian ayat-ayat tersebut di diklasifikasi menurut sebab turunnya yang kemudian ditelusuri relevansinya dan analisis ayat-ayat tersebut guna menemukan konsep yang valid. Dari hasil penelusuran dirumuskan suatu kesimpulan bahwa; ishlah merupakan salah satu wacana yang sangat urgen dan signifikan dalam meneta kehidupan yang damai. Itulah sebabnya sehingga terma ishlah yang berakar kata dari shalaha terulang sebanyak 182 kali dalam berbagai ayat. Ayat-ayat yang dimaksud memiliki sebab nuzul dan saling berkorelasi satu dengan lainnya. Tawaran AlQur'an tentang konsep ishlah itu sendiri mengupayakan untuk menciptakan kedamaian dalam rumah tangga, masyarakat dan lingkungan lainnya, termasuk tawaran kedamaian dalam menghadapi peperangan.
\end{abstract}

Kata Kunci: Al-Qur'an dan Ishlah

\section{Pendahuluan}

Al-Qur'an yang kandungannya berlaku dalam ruang dan waktu sepanjang masa (Syumuliyah wa Zamaniyah), memaparkan dan merefleksikan konsep global tentang situasi dan kondisi fenomologis alam yang juga erat kaitannya dengan agama. Fenomena dan problematika tersebut juga merupakan persolan-persolan yang dihadapi manusia yang melibatkan berbagai komponen masyarakat dan individu dalam berbagai konteks kehidupan. Salah satu bentuk solusi yang ditawarkan untuk menyikapi situasi dan kondisi yang urgen seperti di atas adalah Al-ishlah, yaitu perdamaian.

Tawaran ishlah dapat dilihat pada klausa إصنالَحِ بَيْنَ النَّاسِ yang berarti 


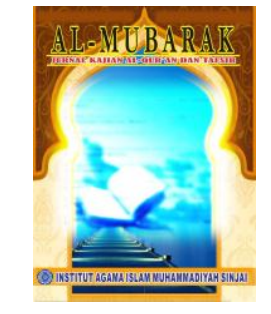

Al-MUBARAK

Jurnall Kajian Al-Quran \& Tafsir

Volume 4, No. 2, 2019

P-ISSN: 2548-7248

E-ISSN: 2715-5692

Homepage : http://journal.iaimsinjai.ac.id/indeks.php/al-mubarak

“perdamaian di antara manusia”. Term ishlah di sini berasal dari kata alshullahu yang diambil dari akar kata al-shulhu (Louis Ma'luf, 1977: 432). Berkaitan dengan hal ini, al-Ashfahani menjelaskan bahwa term al-shulhu adalah بختص بإز الة النفار بين الناس (Dikhususkan peng-gunaannya untuk menghindarkan perpecahan di antara manusia) yang berarti bahwa term alshulhu atau al-ishlah dalam berbagai berbagai ayat dapat dibatasi pemaknaannya dalam arti "perdamaian” (al-Raghib al-Ashfahani, 1992: 489).

Universalitas kata as-shulhu pada ayat tersebut memberikan informasi bahwa berbuat baik dengan cara berbisik boleh saja, khususnya kepada orang yang menduduki jabatan bila mereka diberi nasihat atau bahan dengan cara yang halus, yakni berbisik dengannya maka akan bermafaat dan tentu lebih etis guna menghindari perselisihan, karena seringkali terjadi perselisihan di antara orang yang disegani oleh orang banyak hanya karena cara ishlah yang tidak sesuai dengan naluri orang lain atau karena cara seseorang memberikan informasi yang tidak etis sehingga menimbulkan konsekuensi yang kurang sopan dari pihak yang lain. Sehinggat dibutuhkan konsep dan etika serta metode yang dalam menanganinya secara sulhan sehingga dapat mewujudkan perdamaian yang hakiki dan tidak menimbulkan perselisihan (Hamka, 1983: 275).

Pendeknya, al-Quran menekankan perlunya perdamaian dalam segala lini kehidupan, agar tercipta kehidupan yang penuh damai, makmur dan sentosa dan akan bermuara pada adanya saling hormat menghormati sesama manusia dalam bingkai persaudaraan. Sebagaimana yang terekam dalam QS. al-Hujurat/49: 9 yang menekankan perlunya mempertahakan sikap persaudaraan antara sesama mu'min (ukhuwwah al-islamiyah) dengan cara ishlah.

Dalam konteks ini M. Quraish Shibab menyatakan bahwa ishlah digunakan untuk memperbaiki dan mendamaikan per-tentangan yang terjadi di kalangan kaum muslimin. Untuk menciptakan kedamaian, perlu pula 


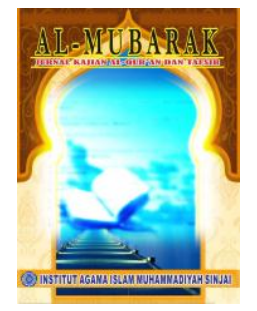

Al-MUBARAK

Jurnall Kajian Al-Quran \& Tafsir

Volume 4, No. 2, 2019

P-ISSN: 2548-7248

E-ISSN: 2715-5692

Homepage : http://journal.iaimsinjai.ac.id/indeks.php/al-mubarak

adanya sikap keadilan dalam awal proses perdamaian itu, karena sikap keadilan sangat urgen artinya dan terkhusus lagi kepada mereka yang bertindak sebagai juru damai setelah mereka menindak tegas kelompok pembangkan. Ini karena besar kemungkinan mereka pun mengalami kerugian, harta jiwa, atau paling tidak harga diri akibat ulah para pembangkan.(M. Quraish Shihab, 1996: 119).

Dapatlah dipahami bahwa konsep ishlah yang ditawarkan Al-Qur`an merupakan benteng keretakan persaudaraan dan sebagai wacana menghindarkan diri dari segala bentuk permusuhan. Dengan demikian, pembahasan tentang ishlah menurut perspektif Al-Qur`an sangat menarik untuk dikaji secara cermat dan mendalam dengan pokok permasalahannya adalah bagaimana konsep ishlah menurut perspektif Al-Qur`an?

\section{Metode}

Sistem pembahasan pada kajian ini menggunakan metode pendekatan ilmu tafsir yang berkaitan langsung dengan tafsir tematik dengan mengikuti beberapa langkah-langkah operasional yang ada di dalamnya yaitu; Menghimpun ayat Al-Qur`an yang berkenaan dengan ishlah (Fuad Abd alBâqî). Ayat-ayat tersebut disusun secara kronologis berdasarkan tertib turunnya. Makkiyah kemudian Madaniyah secara sistematis menurut kerangka pembahasan yang telah disusun (Ahmad an-Naisabûrî). Mengungkap korelasi (munasabah) ayat-ayat. Memberi uraian dan penjelasan yang terkandung dalam ayat dengan menggunakan beberapa teknik analisis (interpretasi) dengan mengunakan library research dalam mengumpulkan datanya yang kemudian dianilisis secara deduktif dan induktif serta komparatif.

\section{Pembahasan}

\subsection{Konsep Ishlah}

\section{a. Definisi Ishlah}

Kata ishlah berasal dari bahasa Arab yang berakar kata shalaha, terdiri atas

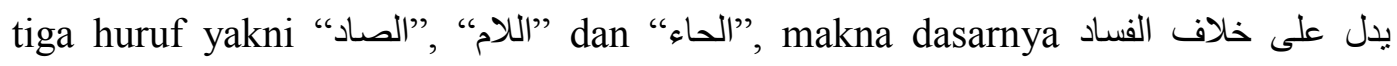




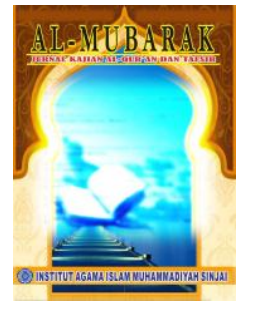

\section{Al-MUBARAK}

Jurmall Kajian Al-Quran \& Tafsir

Volume 4, No. 2, 2019

P-ISSN: 2548-7248

E-ISSN: 2715-5692

Homepage : http://journal.iaimsinjai.ac.id/indeks.php/al-mubarak

(pengertiannya menunjuk pada arti kebalikan dari kerusakan) (Ibnu Fâris, 1979: 303). Dalam beberapa buku Kamus ditemukan pengertian kata shalah yang sangat bervariasi yang antara lain; baik, tidak rusak, tidak binasa, saleh, patut, damai, bermanfaat (Mahmud Yunus, 1992: 219), al-silmu (keselamatan) dan khilafu takhasamah (kebalikan dari permusuhan) (Louis Ma'luf, 1977: 432). Sedangkan dalam bahasa Indonesia ishlah yang berarti perdamaian adalah terjalinnya suasana yang aman dan rukun dalam segala bidang (Departemen Pendidikan dan Kebudayaan RI, 1992: 82).

Berdasar dari pengertian-pengertian di atas, maka ishlah yang dimaksudkan di sini adalah suatu suasana yang diliputi dengan keamanan, ketertiban dan kerukunan dalam berbagai hal. Dalam arti yang lebih luas, maka ishlah terkait dengan persatuan dan per-saudaraan dalam kehidupan.

\section{b. Term-Term Ishlah}

Di dalam al-Quran, penggunaan term-term yang berakar kata dari shalaha (صلح) terulang sebanyak 180 kali (Fu'ad abd al-Bâqî, 1992: 520-523). Dari akar kata shalaha itulah, di-tashrif menjadi wazan ashlaha, yushlihu, ishlahan. Tetapi, tidak semua kata yang berderivasi demikian diartikan "perdamaian”. Dalam bentuk kata kerja yang tidak memerlukan obyek penderita (fi'il muta'adi) disebut dua kali, yakni QS. Al-Ra'd/13: 23 dan QS. al-Mu'min/40: 8. Ayat tersebut memberikan informasi tentang orang-orang yang masuk syurga adalah mereka yang sejahtera, bebas dari kerusakan dan penyakit rohani. Sementara itu, kata shalih sebagai kata sifat isim fa'il dari shalaha dalam berbagai bentuknya disebut 137 kali. Kata shalih dalam bentuk mufrad disebut 46 kali dan sembilan di antaranya kata tersebut menunjuk kepada Nabi Shaleh as. (Fu'ad abd al-Bâqî, 1992: 521). Kata shalih sebagai bentuk isim fa'il dari shalaha, di samping menunjuk perbuatan-perbuatan yang terpuji, benar dan baik, juga menunjuk kepada orang-orang yang memiliki sifat dan perilaku yang terpuji. Karenanya, kata shalih yang menunjukkan sifat umumnya dirangkaian dengan kata amal. Dengan demikian sesuatu yang baik, benar terpuji dan berguna seharusnya diwujudkan dalam perbuatan nyata. 


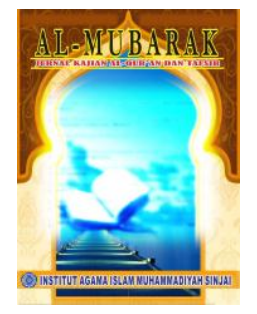

Al-MUBARAK

Jurnall Kajian Al-Quran \& Tafsir

Volume 4, No. 2, 2019

P-ISSN: 2548-7248

E-ISSN: 2715-5692

Homepage : http://journal.iaimsinjai.ac.id/indeks.php/al-mubarak

Dari kata shalih yang menjadi ashlaha (isim tafdhil) inilah kemudian ditashrif mashdar menjadi ishlah, yang di dalam Al-Qur`an penggunannya dalam bentuk kata kerja lampau (fi'il madhi), disebut 14 kali, dalam bentuk kata kerja sedang/sekarang (fi'il mudhari') disebut 8 kali dan bentuk perintah (fi'il amr) disebut 6 kali, sedang selebihnya dalam bentuk isim fa'il lima kali (Fu'ad abd alBâqî, 1992: 521).

Penggunaan kata ishlah di dalam al-Quran secara umum memberikan petunjuk ketika nilai kodrati tidak berfungsimaka diperlukan perbaikan. Sehingga di dalam al-Qur`an, penggunaan kata-kata ishlah seringkali diartikan sebagai perdamaian karena konsep perdamaian terwujud dengan adanya perdamaian. sehingga kata ishlah sering dikontraskan dengan al-fasad (kerusakan). Misalnya, dalam QS. al-A'raf/7: 142 dan QS. Yunus/10: 81.

Di samping kedua ayat di atas, masih ditemukan pula penggunaan kata ishlah yang dikontraskan dengan al-fasad (QS. al-Syu'ara'/26: 152 dan QS. al$\mathrm{Naml} / 27: 48)$.

Namun, untuk kedua ayat disebutkan di atas, khusus berkenaan dengan kisah kemukjizatan yang dimiliki Nabi Musa as. Kekontrasan kata al-shalah atau al-ishlah dengan kata al-fasad dimaksudkan untuk menghindari kerusakankerusakan yang kemungkinan terjadi setelahnya, yang mana mencakup pengrusakan tumbuhan, generasi manusia dan keharmonisan lingkungan, seperti yang diisyaratkan dalam QS. al-Baqarah/2: 205, Keengganan menerima kebenaran, sebagaimana dalam QS. Ali Imran/3: 63, Perampokan, pembunuhan dan gangguang keamanan, sebagaimana dalam QS. al-Maidah/5: 32, Pengurangan takaran, timbangan dan hak-hak manusia, sebagaimana dalam al-A'raf/7: 86, Usaha memecah belah kesatuan, sebagaimana dalam QS. al-Anfal/8: 73, Berfoyafoya dan bermewah-mewah sebagaimana dalam QS. Hud/11: 115-116, Pemborosan, sebagaimana dalam QS. al-Syu'arah/26: 152, Makar dan penipuan, sebagaimana dalam QS. al-Naml/27: 49, Pengorbanan nilai-nilai agama, sebagaimana dalam QS. Ghafir :26, Kesewenang-wenangan, sebagaimana dalam QS. al-Fajr/89: 12 (M. Quraish Shihab, 1996: 480-481). 


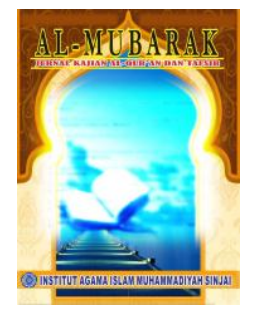

Al-MUBARAK

Jurmall Kajian Al-Quran \& Tafsir

Volume 4, No. 2, 2019

P-ISSN: 2548-7248

E-ISSN: 2715-5692

Homepage : http://journal.iaimsinjai.ac.id/indeks.php/al-mubarak

Pencegahan hal-hal di atas merupakan bagian dari ishlah. Semakin tinggi

nilai kualitas hidup manusia, demikian pula sebaliknya. Ringkasnya, dalam menghadapi kehidupan dunia ini, al-Qur`an memerintahkan manusia agar melakukan ishlah dan shalah, serta melarang melakukan fasad dan ifsad. Dengan menyimak penggunaan term-term ishlah di atas, dapatlah dipahami bahwa esensi ishlah adalah perwujudan perbaikan hubungan kepada sesama yang tentunya bermuara pada perlunya perdamaian dalam kehidupan.

\section{c. Klasifikasi Jenis Ishlah}

Ishlah yang merupakan metode perdamaian yang dipergunakan dalam penyelesaian problematika atau fenomena yang dihadapi oleh individu-individu manusia. Sehingga dapat disimpulkan bawah makna esensial dari ishlah pada hakikatnya berawal dari perwujudan perbaikan kemudian bermuara pada perdamaian. Dan daripadaitu dikemukakan bahwa dalam klasifikasi Jenis ishlah dalam beberapa jenis yaitu:

Pertama: Ishlah dalam akidah dimana Mahmud Syaltut yang mendefinisikan akidah sebagai suatu teori yang perlu dipercayai terlebih dahulu sebelum yang lain, di mana kepercayaan itu harus bulat dan penuh, tidak bercampur dengan keraguan (Mahmud Syaltut, 1996: 11). Berbeda dengan pejelasan tersebut Imam Munawwir menjelaskan bahwa perdamaian akidah terdiri dari perdamaian dalam berpikir dan perdamaian dalam soal keyakinan atau kepercayaan (Imam Munawir, 1992: 46 dan 49). Perdamaian dalam berpikir, berarti setiap orang tidak boleh memaksakan pendapat serta kehendak orang lain. Karena itulah, Islam menghendaki kepada setiap manusia untuk menggunakan pikirannya dengan sebaik-baiknya sebagaimana yang dijelaskan dalam QS. Yunus/10: 24. Penjelasan ini memperkuat konsekuensi bahwa Islam mewajibkan perdamaian dalam soal kepercayaan antara pemeluk agama yang dibatasi dengan ketidaadaan paksaan dalam memilih dan menjalankan agamany karena ayat-ayat al-Qur`an dengan tegas membenarkan paksaan itu sebagai alat buntuk membawa seseorang ke dalam Islam dan melarang kaum muslimin memaksa orang lain masuk agamanya (Imam Munawir, 1992: 49 dan 50). Kolerasi dari hal tersebut di defenisikan bahwa tekemerdekaan kepercayaan dapat diklasifikasikan dalam tiga 


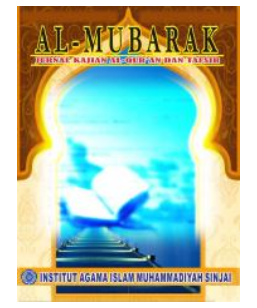

\section{Al-MUBARAK}

Jurmall Kajian Al-Quran \& Tafsir

Volume 4, No. 2, 2019

P-ISSN: 2548-7248

E-ISSN: 2715-5692

Homepage : http://journal.iaimsinjai.ac.id/indeks.php/al-mubarak

unsur penting yaitu pemikiran yang bebas dan tidak terikat oleh kefanatikan kebangsaan atau ikut-ikutan (taklid), syahwat atau hawa nafsu. Karena kerapkali terjadi bahwa hawa nafsu dan kefanatikanlah yang merajalela atas nama agama. Larangan penggunaan bujukan atau paksaan untuk menarik kepada kepercayaan. Islam tidak menganggap seseorang sebagai penganut agama yang bebas, bila ia memeluk agama itu di bawah tekanan dan bujukan-bujukanh. Beramal sesuai dengan kepercayaan dan memudahkannya bagi setiap penganut agama tanpa sesuatu penyulitan (Imam Munawir, 1992: 51).

Kedua: Ishlah dalam Kehidupan Pribadi, dimana kehidupan peribadi ini sangat berkaitan dengan prilaku manusianya yang biasa diistilahkan dengan akhlak atau budi pekerti sebagaimana yang dijelaskan oleh al-Gazaly bahwa cerminan pribadi manusia adalah akhlaknya (al-Ghazâlî, t.th.: 52).

Pribadi manusia tersebut diidentikkan diantara Mahmudah dan Mazmumah. Konsep Pribadi ini ditemukan dalam al-Qur'an sebagai konsideran atas pengakuan Allah atas sifat Nabi saw. Yang terdapat dalam QS. al-Qalam/68: 4 Jadi, akhlak merupakan etika dasar yang dimiliki seseorang dan merupakan refleksi tabiatnya, jika tabiatnya baik maka baik pula perilakunya sebagai cerminan keimanan seorang Muslim.

Potensi manusia dalam melakukan ishlah terhadap pribadinya telah telah timbul sejak ia mengenal kebaikan. Kecenderungannya yang mendasar kepada kebaikan, seharusnya mengantarkan manusia memperkenan-kan perintah Allah (agama-Nya) yang dinyatakan-Nya sesuai fithrah (asal kejadian manusia). Di sisi lain, karena kebajikan mereka pilihan manusia, kelak dikemudian pada saat pertanggungjawaban, sang manusia dihadapkan pada dirinya sendiri (M. Quraish Shihab, 1989: 258).

Ketiga adalah ishlah dalam hubungan umum di antara manusia dengan manusia lainnya. Konstitusi Islam juga mewajibkan perdamaian atau ishlah antara manusia. Itulah sebabnya sehingga manusia dijadikan berbangsa-bangsa dan bersuku-suku, yang tiada lain berguna untuk saling berdamai (QS. al-Hujurat/49: 13). Pada saat yang sama, konsepsi tetntang tanggung jawab manusia mengandung kewajiban untuk mengakui, memelihara dan menetapkan 


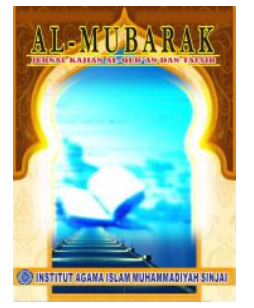

Al-MUBARAK

Jurmall Kajian Al-Quran \& Tafsir

Volume 4, No. 2, 2019

P-ISSN: 2548-7248

E-ISSN: 2715-5692

Homepage : http://journal.iaimsinjai.ac.id/indeks.php/al-mubarak

kehormatan diri sendiri. Dalam pandangan ganda inilah, yakni kehormatan pribadi dan kehormatan antara sesama manusia harus saling memahami (Imam Munawir, 1992: 56). Islam mendidik agar setiap pemeluknya cinta damai, mengambil berbagai sarana yang dapat mengantarkan serta merealisasikannya ke arah itu. Itulah sebabnya sehingga Islam memulai memulai ajarannya dengan cintai damai dalam berdakwah di tengah-tengah manusia (Ahmad Muhammad Jamal, 1991: 48). Ishlah di antara manusia yang dianjurkan oleh Islam, adalah sebagaimana yang telah praktekkan oleh Nabi saw sejak awal diutusnya, sebagaimana dalam QS. al-Nahl/16: 125.

Keempat: Islam berpendirian bahwa bersatunya manusia dengan masyarakat adalah suatu keharusan. Watak manusia tidak memungkinkan hidup terpencil. Tersusunnya masyarakat sebagai akibat dari ketidakmampuanh ini, keperluan manusia untuk berkelompok itu sesungguhnya berganda. Di satu pihak, keinginan untuk dominasi dan agresi yang merupakan watak pembawaan manusia, dapat mendorongnya kepada tindakan tanpa pikiran atau merusak. Otoritas dan kekuasaan yang memaksa adalah satu-satunya sarana yang dapat mengatasi rasa dengki, kesombongan, kecurigaan, keangkuhan pribadi dan dengan begitu melindungi warga kelompok secara timbal balik.

Hal ini tidak dapat dipungkiri karena manusia tidak mempunyai kemampuan untuk memuaskan segala kebutuhan pribadinya. Kerja sama dan tolong menolong menjadi keharusan bagi manusia jika ia tidak mau musnah. Kehidupan dalam masyarakat memperoleh kekuatan yang memaksa "diri sendiri" oleh karena dengan hidup dalam masyarakat itu manusia mendapatkan makanan untuk dapat hidup dan senjatanya untuk mempertahankan diri sendiri. Dalam pada itu, ia juga mendapat jaminan keamanan dan keuntungan dari tolong menolong (Imam Munawir, 1992: 57-58). Ahmad Muhammad Jamal kemudian menerangkan bahwa langkah perdamaian dalam masyarakat Islam haruslah direalisasikan amar ma'ruf dan nahi mungkar dan saling berwasiat kebenaran antara anggota masyarakat. Di samping itu, harus pula direalisasikan had (balasan) dan menentukan hukuman terhadap orang-orang yang mencoba berbuat zalim terhadap jiwa, kehormatan dan hartav benda, juga terhadap orang-orang yang 


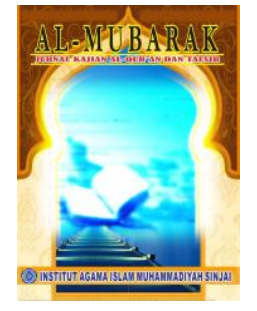

Al-MUBARAK

Jurnall Kajian Al-Quran \& Tafsir

Volume 4, No. 2, 2019

P-ISSN: 2548-7248

E-ISSN: 2715-5692

Homepage : http://journal.iaimsinjai.ac.id/indeks.php/al-mubarak

membuat kerusakan hingga mengusik kedamaian dan kehidupan manusia di muka bumi ini (Ahmad Muhammad Jamal, 1991: 48).

Dengan demikian, ishlah dalam masyarakat menyebabkan struktur masyarakat itu terjalin dengan baik, karena adanya tenggang rasa, tolong menolong, bahu membahu dan tanggung jawab bersama. Dengan itu, maka pertentangan satu sama lain dapat dihindarkan. Kelima: Islam mewajibkan adanya keadilan dalam pemerintahan serta persamaan dalam hak-hak bagi semua orang yang dinaungi sistem Islam, walaupun di antara mereka terdapat non Muslim (Imam Munawir, 1992: 51). Konsep ishlah dalam pemerintahan ini, telah terealisasi sejak zaman Nabi saw, dengan diproklamirkannya "Piagam Madinah" yang antara lain berisi tentang prinsip perdamaian antara kaum kafir dengan umat Islam. Bagi mereka non Muslim tetap dilindungi oleh pemerintah Islam, mereka yang dilindungi inilah disebut dengan ikafir zimmi (J. Suyuti Pulungan, 1996: $150)$.

\section{d. Ayat-Ayat Ishlah dan Sebab Turunnya}

Mengkaji tentang ishlah tidak dapat dilepaskan dengan pengklasifikasian ayat-ayat yang berkaitan dengan ishlah itu sendiri sehingga pada kajian ini akan di paparkan ayat-ayat yang berkaitan dengan ishlah dan konsep turunnya. Adapun metode yang terpakai dalam menentukan kriteria ayat-ayat ayat ishlah digunakan beberapa pendekatan, yaitu; Metode al-Sumaiy al-Naqliy dan Metode al-Qiyas alIjtihadiy (Mannâ' al-Qaththan, 1973: 61). Sehingga dalam penelaahan yang dilakukan tersimpulkan bahwa berkaitan tentang konsep ishlah dalam al-Qur'an tidak ditemukan ayat ishlah yang klasifikasinya makkiyah. Hal ini menunjukkan bahwa persoalan ishlah hanya dapat ditemukan dalam ayat-ayat madaniyah.

Berdasarkan metode al-Suma 'iy al-Naqliy dan metode al-Qiyas al-Ijtihadiy, maka ditemukan bahwa ayat-ayat tentang ishlah terdapat dalam QS. al-Baqarah/2: 228; QS. al-Nisa/4: 35, 114, 128; al-Anfal/8: 1; dan al-Hujurat/49: 9-10. Berikut ini dikemukakan surah-surah dan ayat-ayat serta sebab nuzul-nya yang bekenaan dengan ishlah yang tergolong Madaniyah : 


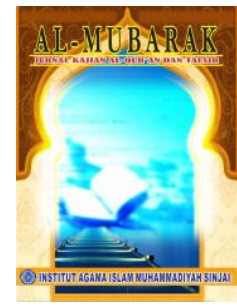

Al-MUBARAK

Jurmall Kajian Al-Quran \& Tafsir

Volume 4, No. 2, 2019

P-ISSN: 2548-7248

E-ISSN: 2715-5692

Homepage : http://journal.iaimsinjai.ac.id/indeks.php/al-mubarak

1. QS. al-Baqarah/2: 228

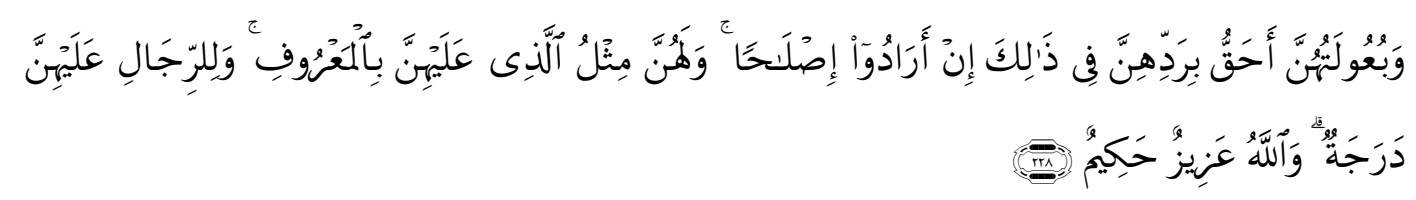

Terjemahnya:

"Dan suami-suaminya berhak merujukinya dalam masa menanti itu, jika mereka (para suami) itu menghendaki ishlah. Dan para wanita mempunyai hak yang seimbang dengan kewajibannya menurut cara yang ma`ruf. Akan tetapi para suami mempunyai satu tingkatan kelebihan daripada isterinya. Dan Allah Maha Perkasa lagi Maha Bijaksana" (Departemen Agama RI, 2012: 55).

As-Suyuti mengomentari bahwa asbab nuzul ayat ini berkenaan dengan kasus Asma binti Yazid. Di mana ia berkata; Aku dithalaq oleh suamiku di zaman Rasulullah saw di saat belum ada hukum iddah bagi wanita yang dithalak, maka menetapkan hukum iddah bagi wanita yaitu menunggu setelah bersuci dari tiga kali haid (al-Suyuthi, 1974: 74). Dengan adanya term Ishlah dalam ayat ini, mengindikasikan bahwa sebaiknya seorang suami merujuk isterinya ketika sang isteri tersebut sudah tiga kali suci. Dalam hal ini, rujuk yang dimaksud adalah berishlah atau berdamai dalam rangka mewujudkan rumah tangga yang sakinah. Berbeda halnya al-Maragiy yang menyebutkan bahwa ketika suami ingin rujuk dengan isteri dalam masa iddah, tapi niatnya bukan untuk ishlah dalam arti memperbaiki hubungannya dan bergaul dengan baik, maka hal itu dilarang oleh agama (al-Maragiy, 1984: 308).

2. QS. al-Nisa/4: 35

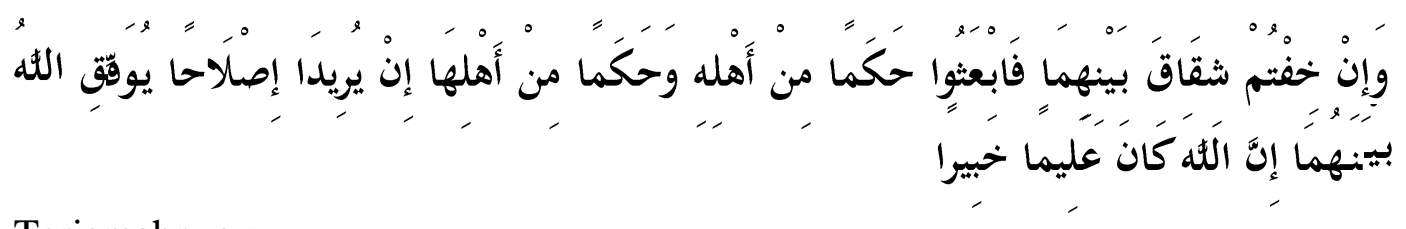

Terjemahnya :

"Dan jika kamu khawatirkan ada persengketaan antara keduanya, maka kirimlah seorang hakam dari keluarga laki-laki dan seorang hakam dari keluarga perempuan. Jika kedua orang hakam itu bermaksud mengadakan perbaikan, niscaya Allah memberi taufik kepada suami-isteri itu. Sesungguhnya Allah Maha Mengetahui lagi Maha Mengenal” (Departemen Agama RI, 2012: 123). 


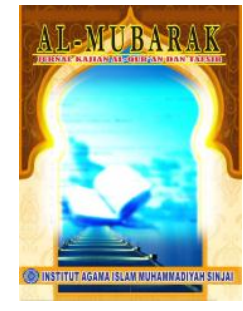

\section{Al-MUBARAK}

Jurmall Kajian Al-Quran \& Tafsir

Volume 4, No. 2, 2019

P-ISSN: 2548-7248

E-ISSN: 2715-5692

Homepage : http://journal.iaimsinjai.ac.id/indeks.php/al-mubarak

Dalam ayat ini kembali assuyuti menjelaskan Sebab nuzul ayat di atas bersamaan dengan ayat sebelumnya, yakni ayat 34 yang dikisahkan bahwa ada seorang isteri dari golongan Anshar yang mengadu kepada Nabi saw, karena ditampar oleh seseorang dan isteri tersebut menuntut hukum qishash (balas). Nabi saw. Mengabulkan tuntutan itu dan turunlah ayat sebagai mana yang dikutip di atas (al-Suyuthi, 1974: 126). Menurut Hamka Haq bahwa hukum qishas dalam Islam boleh ditiadakan, jikalau pihak yang berbuat itu minta maaf dan pihak yang dirugikan memaafkannya serta ia dibayar sesuai dengan yang ditetapkannya (Hamka Haq, 2001: 8).

3. QS. al-Nisa/4: 114

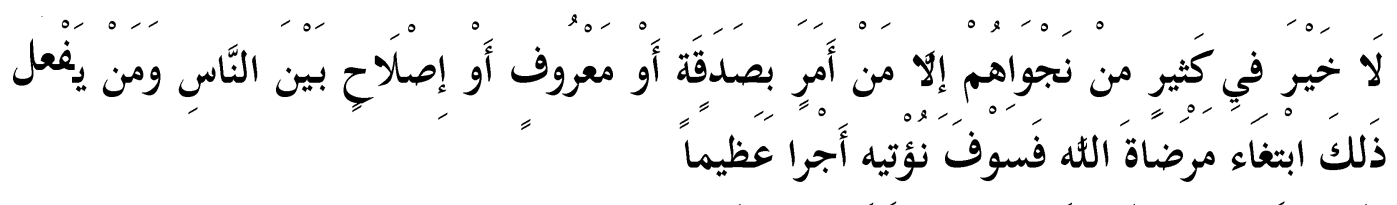

Terjemahnya:

"Tidak ada kebaikan pada kebanyakan bisikan bisikan mereka, kecuali bisikan-bisikan dari orang yang menyuruh (manusia) memberi sedekah, atau berbuat ma`ruf, atau mengadakan perdamaian di antara manusia. Dan barangsiapa yang berbuat demikian karena mencari keredhaan Allah, maka kelak Kami memberi kepadanya pahala yang besar" (Departemen Agama RI, 2012: 134).

Sebab nuzul ayat di atas, kisahkan bahwa Suraqah bin Malik bercerita tentang perang Badr dan Uhud, di mana orang-orang di sekeliling Madinah Masuk Islam dan ia mendengar berita dari Nabi akan mengirim pasukan Khalid bin Walid ke kaumnya (Bani Mudlaj). Ia menghadap Nabi saw dan berkata : "Saya mohon perlindungan tuan dengan sungguh-sungguh untuk diadakan perdamaian dengan kaumku, karena telah sampai berita kepadaku bahwa tuan akan mengirim pasukan kepada mereka. Sekiranya kaum Quraisy tunduk, maka kaumkupun akan tunduk dan masuk Islam. Akan tetapi jika mereka belum tunduk pasti kaum Quraisy menyerang dan mengalahkan kaumku”. Kemudian rasulullah saw memegang tangan Khalid bin Walid seraya bersabda : Berangkatlah dengan orang ini dan kerjakanlah apa yang dikehendakinya”. Kemudian Khalid membuat perdamaian dengan mereka supaya berkomplot memerangi Nabi saw dan akan 


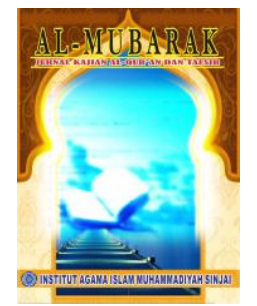

\section{Al-MUBARAK}

Jurnall Kajian Al-Quran \& Tafsir

Volume 4, No. 2, 2019

P-ISSN: 2548-7248

E-ISSN: 2715-5692

Homepage : http://journal.iaimsinjai.ac.id/indeks.php/al-mubarak

tunduk apabila kaum Quraisy telah tunduk. Maka turunlah ayat di atas (alSuyuthi, 1974: 142).

4. QS. al-Nisa/4: 128

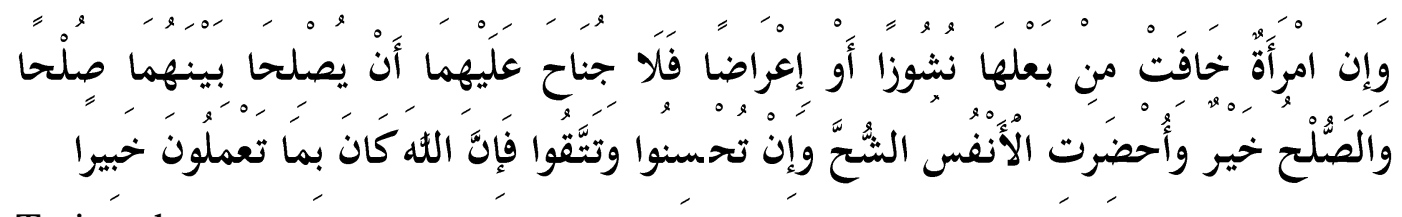

Terjemahnya :

"Dan jika seorang wanita khawatir akan nusyuz atau sikap tidak acuh dari suaminya, maka tidak mengapa bagi keduanya mengadakan perdamaian yang sebenar-benarnya, dan perdamaian itu lebih baik (bagi mereka) walaupun manusia itu menurut tabiatnya kikir, Dan jika kamu bergaul dengan isterimu secara baik dan memelihara dirimu (dari nusyuz dan sikap tak acuh), maka sesungguhnya Allah adalah Maha Mengetahui apa yang kamu kerjakan" (Departemen Agama RI, 2012: 143).

Sebab nuzul ayat di atas, berkenaan dengan Saudah binti Za'mah (isteri Nabi saw) yang sudah tua dan takut diceraikan. Ketika itu, ia berkata kepada Nabi saw : "Hari giliranku aku hadiahkan kepada Aisyah". Maka turunlah ayat di atas (al-Suyuthi, 1974: 159).

5. QS. al-Anfal/8: 1

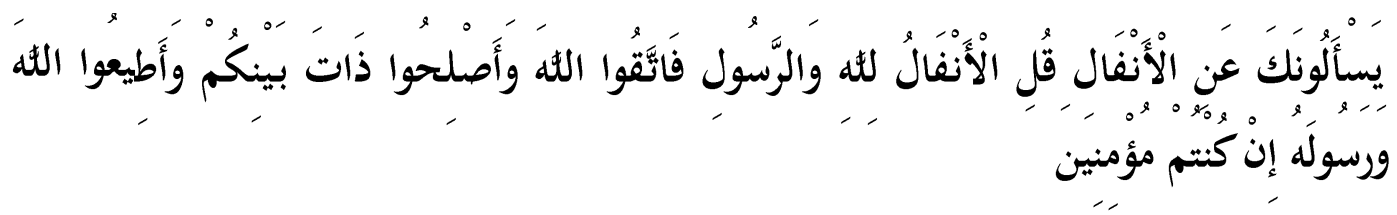

Terjemahnya :

"Mereka menanyakan kepadamu tentang (pembagian) harta rampasan perang. Katakanlah: "Harta rampasan perang itu kepunyaan Allah dan Rasul, sebab itu bertakwalah kepada Allah dan perbaikilah perhubungan di antara sesamamu, dan ta ‘atlah kepada Allah dan Rasul-Nya jika kamu adalah orang-orang yang beriman" (Departemen Agama RI, 2012: 260).

Sebab nuzul ayat di atas, bermula dari pernyataan Nabi saw yang artinya : Barangsiapa yang membunuh (musuh), ia akan mendapat sejumlah bagian tertentu dan barang siapa yang menawan musuh, ia pun akan mendapat bagian tertentu pula. Pada waktu itu, orang-orang tua tinggal menjaga bendera, sedang para pemuda maju ke medan jihad menyerbu musuh dan mengangkat ghanimah. Berkatalah orang tua-tua kepada para pemuda : “Jadikanlah kami sekutu kalian”. 


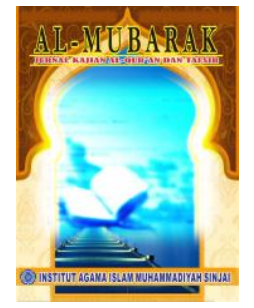

\section{Al-MUBARAK}

Jurmall Kajian Al-Quran \& Tafsir

Volume 4, No. 2, 2019

P-ISSN: 2548-7248

E-ISSN: 2715-5692

Homepage : http://journal.iaimsinjai.ac.id/indeks.php/al-mubarak

Hal ini mereka adukan kepada Nabi saw. Dari kasus ini, turunlah ayat yang disebutkan di atas (al-Suyuthi, 1974: 213).

6. QS. al-Hujurat/49: 9-10.

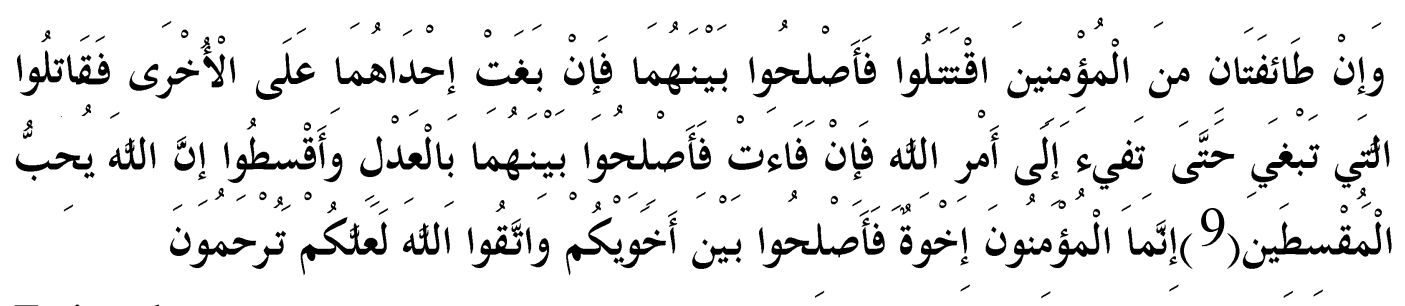

Terjemahnya:

"Dan jika ada dua golongan dari orang-orang mu'min berperang maka damaikanlah antara keduanya. Jika salah satu dari kedua golongan itu berbuat aniaya terhadap golongan yang lain maka perangilah golongan yang berbuat aniaya itu sehingga golongan itu kembali kepada perintah Allah; jika golongan itu telah kembali (kepada perintah Allah), maka damaikanlah antara keduanya dengan adil dan berlaku adillah. Sesungguhnya Allah menyukai orang-orang yang berlaku adil. Sesungguhnya orang-orang mu'min adalah bersaudara karena itu damaikanlah antara kedua saudaramu dan bertakwalah kepada Allah supaya kamu mendapat rahmat" (Departemen Agama RI, 2012: 846).

Asbab nuzul ayat 9 dan 10 di atas, berawal dari kasus antara dua orang Muslim yang bertengkar satu sama lain. maka marahlah para pengikut kedua kaum itu dan berkelahi dengan menggunakan tangan dan sandal. Dalam keadaan demikian turunlah ayat di atas sampai ayat ke 11 (al-Suyuthi, 1974: 458).

Dari berbagai jenis dan term ishlah yang dikemukakan diatas dianalisis bahwa ishlah dalam prihal perdamaian sangat urgen dalam kehidupan manusia untuk menjalin kebersamaan dan keindahan dalam menjalani kehidupan.

\section{Simpulan}

Setelah melakukan pengkajian tentang ishlah dalam al-Qur'an disimpulkan bahwa ishlah dari aspek etimologi memililki banyak pengertian, tetapi batasan pengertian yang sering terpakai dalam al-Qur`an adalah ishlah dalam arti perdamaian dimana ayat-ayat tentang ishlah hanya ditemukan dalam surah-surah Madaniyah yang secara global menawarkan konsep ishlah dalam rumah tangga, ishlah dalam masyarakat, ishlah dalam peperangan. Dengan merealisasikan konsep ishlah dalam kehidupan, diharapkan untuk mempertahankannya dan 


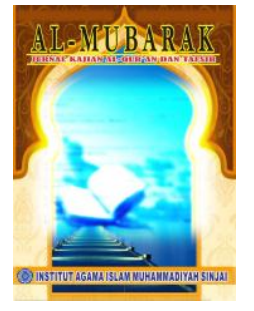

\section{Al-MUBARAK}

Jurmall Kajian Al-Quran \& Tafsir

Volume 4, No. 2, 2019

P-ISSN: 2548-7248

E-ISSN: 2715-5692

Homepage : http://journal.iaimsinjai.ac.id/indeks.php/al-mubarak

memelihara dengan baik, sehingga tercipta kerukunan dan toleransi dalam bermasyarat baik sesama keluarga, sesama masyarakat muslim, maupun terhadap mereka yang non muslim. Kajian lebih lanjut tentang ishlah, tentu masih masih perlu ditinjau dan dicermati secara arif dan bijaksana, guna merumuskan suatu konsep yang lebih valid dan akurat, sehingga manfaatnya berguna untuk kepentingan ilmiah khusunya dalam pengkajian ilmu-ilmu keislaman.

\section{Daftar Pustaka}

Al-Ashfahani, al-Raghib. (1992). Mufradat Alfazh al-Qur'an. Dimasyqi: Dar alQalam.

Al-Baqy, Muhammad Fu'ad Abd. (1992). Al-Mu'jam Mufahras Li Alfahz alQur'an al-Karim. t.t.: Dar al-Fikr.

Al-Barmawi, Bakir Yusuf. (1993). Pembinaan Kehidupan Beragama Islam pada Anak. Semarang: Toha Putra.

Departemen Agama RI. (1989). Al-Qur'an dan Terjemahnya. Surabaya: Mahkota.

Departemen Pendidikan dan Kebudyaan RI. (1992). Kamus Besar Bahasa Indonesia. Jakarta: Balai Pustaka.

Al-Gazaliy, Imam Abu Hamid Muhammad bin Muhammad. (t.th.). Ihya 'Ulûm al-Dîn. Kairo: Maktabah Mathba'ah al-Masyâd al-Husayni.

Hamka. (1983). Tafsir al-Azhar. Jakarta: Panjimas.

Haq, H. Hamka. (2001). Penegakan Syariat Islam di Indonesia dalam "Pidato Pengukuhan Guru Besar” pada Fak. Ushuluddin IAIN Alauddin Makassar.

Hasan M. Ali, dan Rifa'at Syauqi Nawawi. (1988). Pengangar Ilmu Tafsir. Jakarta: Bulan Bintang.

Ibn Zakariya, Abu al-Husayn Ahmad ibn Faris. (1979). Mu'jam Maqayis alLugah. t.t.: Dar al-Fikr.

Ismail, Muhammad Bakri. (1991). Dirasat Fiy 'Ulûm al-Qur'ân. Kairo: Dâr alManar.

Jamal, Ahmad Muhammad. (1991). Al-Jihad fiy al-Islam Maratibuhu wa Matahalibuhu, diterjemahkan oleh Ali Makhtum Assalami, dengan judul Perang Damai dan Militer dalam Islam. Jakarta: Fikahati Aneska. 


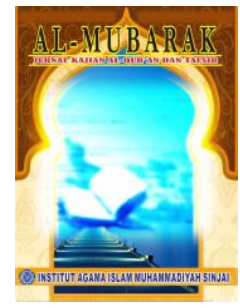

\section{Al-MUBARAK}

Jurnal Kajian Al-Quran \& Tafsir

Volume 4, No. 2, 2019

P-ISSN: 2548-7248

E-ISSN: 2715-5692

Homepage : http://journal.iaimsinjai.ac.id/indeks.php/al-mubarak

Ma'luf, Louis. (1977). Al-Munjid fiy al-Lugah. Beirut : Dar al-Masyriq.

Al-Maragi, Ahmad Mushtafa. (1984). Tafsir al-Maragi, Semarang : Toha Putra.

Munawir, Imam. (1992). Sikap Islam Terhadap Kekerasan Damai Toleransi dan Solidaritas. Jakarta: Bina Ilmu.

Pulungan, J. Suyuti. (1996). Prinisp-prinsip Pemerintahan dalam Piagam Madinah Ditinjau dari pandangan Al-Quran. Jakarta: LSIK dan Rajawali Pres.

Al-Qaththan, Manna' Kahlil. (t.th.). Mabahits fiy 'Ulum al-Qur'an. Beirut: Mansyurat al-Ashr al-Hadits.

Ridha, Muhammad Rasyid. (1993). Tafsir al-Qur'an al-Hakim al-Syahir bi Tafsir al-Manar. Beirut: Dar al-Ma'rifah.

Salim, Abd. Muin. (1995). Fiqh Siyasah; Konsepsi Kekuasaan Politik dalam alQur`an. Jakarta: Raja Grafindo Persada.

Al-Shalih, Shubhi. (t.th.). Mabahits Fi 'Ulum al-Qur'an. Beirut: Dar al-'Ulum.

Shihab, M. Quraish. (1984). Metode Penyusunan Tafsir Yang Berorientasi pada Sastera, Budaya dan Kemasyarakatan. Ujung Pandang: Yusgar. . (1989). Wawasan al-Qur'an; Tafsir Mawdhui atas Pelbagai Persoalan Umat. Bandung: Mizan.

- (2000). Tafsir al-Mishbah; Pesan, Kesan dan Keserasian Al-Quran. Jakarta: Lentera Hati.

_. Tafsir Al-Qur'an Al-Karim. Cet. I; Bandung: Pustaka Hidaya, 1997.

Siddieqy, M. Hasbi Ash. (1993). Ilmu-Ilmu al-Qur'an. Jakarta: Bulan Bintang.

Al-Suyuti, Jalal al-Din. (1974). Lubab al-Nuqul Fiy Asbab al-Nuzul, diterjemahkan oleh K. H. Qamaruddin Shaleh, Asbabun Nuzul; Latar Belakang Historis Turunnya Ayat-ayat al-Quran. Bandung: Diponegoro.

Syaltut, Mahmud. (1996). Al-Islam Aqidatu Wa Syari'ah. Dar al-Kalam.

Yunus, Mahmud. (1992). Kamus Arab Indonesia. Jakarta: Hidakarya Agung. 